\title{
Clinical utility and dilemmas of SNP microarray testing
}

\author{
Virginia Kimonis \\ From International Conference on Human Genetics and 39th Annual Meeting of the Indian Society of \\ Human Genetics (ISHG) \\ Ahmadabad, India. 23-25 January 2013
}

The ability to diagnose patients with developmental delay, intellectual disability, congenital anomalies, and dysmorphic features has significantly improved with the introduction of SNP microarray technologies which includes more than 1.8 million markers on a single array. This high-density array will allow for sensitively detecting all known abnormalities with defined loci of interest as well as the discovery of "new syndromes" as a cause of mental retardation or autism. The most common micro deletion disorders include15q11-q13 Prader-Willi/Angelman, 22q11.3 velo-cardiofacial, 17 pl3.3 William, 1p36and 16p11.2 microdeletion syndromes. SNP arrays are able to detect segmental uniparental disomy (UPD) as in Prader Willi syndrome and UPD14. SNP arrays identify parental consanguinity which may otherwise go undetected. Long stretches of homozygosity can be analyzed for recessive genes in patients born to consanguineous parents. (http://www.ccs.miami.edu/ cgi-bin/ROH/ROH_analysis_tool.cgi)

Arrays cannot however identify balanced chromosomal rearrangements, such as translocations or inversions, Marker chromosomes may also be missed, depending on the size, marker composition, and array coverage of the specific chromosomal region present on the marker. Dilemmas arise when "CNVs of uncertain clinical significance" are identified, or if a parent is not available for testing, thus making it difficult to identify if the rearrangement is inherited or arose de-novo. Further dilemmas arise if a parent is identified with the same rearrangement and is apparently asymptomatic, should one then consider the presence of a mutation in a recessive gene in the other allele to explain autism, mental retardation or other disorders.

Correspondence: vkimonis@uci.edu

Division of Genetics and Genomics, Department of Pediatrics, University of California, Irvine, CA 92868, USA

(c) 2014 Kimonis; licensee BioMed Central Ltd. This is an Open Access article distributed under the terms of the Creative Commons Attribution License (http://creativecommons.org/licenses/by/2.0), which permits unrestricted use, distribution, and reproduction in any medium, provided the original work is properly cited. The Creative Commons Public Domain Dedication waiver (http:// creativecommons.org/publicdomain/zero/1.0/) applies to the data made available in this article, unless otherwise stated.
Overall SNP array technology has become the test of choice, permitting a $5.9 \%$ detection rate in patients with negative microarray-based $\mathrm{CGH}$ and an overall detection rate approaching $29 \%$.

Published: 21 January 2014

doi:10.1186/1755-8166-7-S1-134

Cite this article as: Kimonis: Clinical utility and dilemmas of SNP microarray testing. Molecular Cytogenetics 2014 7(Suppl 1):134.

Submit your next manuscript to BioMed Central and take full advantage of:

- Convenient online submission

- Thorough peer review

- No space constraints or color figure charges

- Immediate publication on acceptance

- Inclusion in PubMed, CAS, Scopus and Google Scholar

- Research which is freely available for redistribution
C Biomed Central

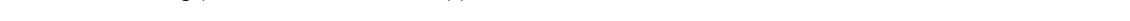

